\title{
Possessive Relational Process Clauses in Scientific Text: Implication on ESP Teaching
}

\author{
Mulyati Khorina \\ Jurusan Bahasa Inggris, Politeknik Negeri Bandung, Indonesia \\ E-mail: mulyati.khorina@polban.ac.id
}

\begin{abstract}
This paper focuses on possessive relational process clauses which is a type of relational process clauses in which relational processes work. Three points concerning possessive relational process clauses are discussed in this paper. First, the relational process type which is dominant possessed by possessive relational process clauses. Second, the lexical verbs which realize the dominant type of relational process. The last, the roles played by possessive relational process clauses. The data for this study were taken from Electrical Circuit Theory and Technology, Fundamentals of Electronics Circuits, Electronics Devices, Flow Version, and A Textbook of Electrical Technology, all of which are used as references by Electronics Engineering students of PoliteknikNegeri Bandung. To analyse the data, Systemic Functional Linguistics (SFL) was employed. The results showed that possessive relational process clauses in scientific texts operate solely on attributive relational process. The attributive relational process is realized by lexical verbs have, consist, include, make which represent the possessive relational process clauses as Classification, Composition and Feature.
\end{abstract}

Keywords: possessive relational process clauses, classification, composition, feature

\section{INTRODUCTION}

English for Specific Purposes (ESP) refers to the teaching and learning of English as a second or foreign language where the goal of the learners is to use English in a particular domain as defined by Paltridge and Starfield (2013, 2). The particular domain suggests that ESP is strongly influenced by the context either culture or situation in which the language is used. Context of culture results in genre of the language used. For example, the language used by doctors to their patients will be different from the one they use among their colleagues. Meanwhile, context of situation through register components consisting of field, tenor and mode will also define the language used or what is called text (Halliday and Hasan, 1976 in Halliday and Matthiessen, 2014). This implies that ESP possesses particular characteristics, Dudley-Evans and St John (1988, 4-5) in Basturkmen $(2010,13)$ formulated the particular characteristics of ESP into two broad categories: absolute and variable (Figure 1). 
1. Absolute characteristics

- ESP is designed to meet specific needs of the learners;

- ESP makes use of the underlying methodology and the activities of the discipline it serves;

- ESP is centred on the language (grammar, lexis, register), skills, discourse and genres appropriate to these activities.

2. Variable characteristics

- ESP may be related to or designed for specific disciplines;

- ESP may use in, in specific teaching situations, a different methodology from that of general English;

- ESP is likely designed for adult learners, either at tertiary level institution or in professional work situation. It could, however, be used for learners at secondary school level;

- ESP is generally designed for intermediate or advanced students. Most ESP courses assume basic knowledge of the language system, but it can be used with beginners.

Figure 1 Definition of absolute and variable characteristics of ESP (Dudley-Evans and St John (1998, 4-5) in Basturkmen (2010, 13)

Based on the discussion above, it could be inferred that ESP isunique compared with GE. ESP will be different due to its register which leads to lexico-grammar choices. Halliday (1993) argued that the lexico-grammar simultaneously becomes the feature of English scientific texts and the barrier for the learners to comprehend the texts. In line with Halliday, Wellington and Osborne (2002) found that the major difficulty of learning science is the language of science. Therefore, to help students or learners gain the knowledge of their discipline, they have to understand the language used in the texts where the knowledge is being discussed. This is because, as argued by Schleppegrell (2004:5) students need to use language in particular ways in order to be successful in science, history, and other subjects; to develop interpretations, construct arguments, and critique theories. To provide students to such kind of language, it is necessary to decompose the structure of the language to find out what functions the structure or the grammar play in the text. Furthermore, Martin (1992) stated that the 
language of science is commonly dominated by relational process. This process occurs in relational process clauses divided into three types: intensive, possessive and circumstantial (Halliday, 1994). The clauses serve specific roles in scientific texts (Martin, 1992; Khorina, Suyatna, and Indira, 2017; Bahtera, 2018). Hence, this paper will discuss how the roles of one type of relational process clauses, i.e., possessive relational process clause implicates teaching ESP in terms of lexico-grammar.

\section{LITERATURE REVIEW}

\section{Possessive relational process clause in scientific texts: the roles}

Possessive clauses concern with ' $\mathrm{X}$ has $\mathrm{Y}$ '. In other words one entity possesses another as stated by Halliday and Matthiessen (2014). For example: Pieter has a piano. This clause shows that Pieter is the entity who possesses another entity, that is, a piano. The clause is called possessive clause because the process realized by verb has indicates ownership. So the role played by the clause is to describe ownership or possession. However, in scientific texts, possessive relational process clauses have several roles as identified by Wignell, Martin and Eggin (1993) and Khorina, Suyatna, and Indira (2017). The roles are Classification, Composition, and Properties which are exemplified below.

\section{Classification}

The first role played by possessive relational process clause is Classification. Classification is a nature of scientific thinking (Darian, 2003). The scientific thinking is represented semantically in hyponymy. Hyponymyis a relation of inclusion in whichahyponymincludes the meaning of a moregeneral word (Sayeed, 2003:68). Example, hammer, saw, chisel are hyponyms of tool. The relationhip between tool and its hyponyms is vertical which can be expressed syntactically by using possessive relational process clause. Khorina et al (2017) studied this role which occurs in Electronics and Energy engineering texts while Bahtera (2018) investigated it in Accounting texts. Some instances are seen below.

1) The main types include variable air, mica, paper, ceramic, plastic, titanium oxide and electrolytic. 
2) These techniques include combining resistors in series or parallel, voltage division, and delta-to-wye and wye-to-delta transformations.

3) Product costs consist of direct materials, direct labor, and overhead.

4) The conversion costs category can be broken down into direct labor and overhead.

5) A master budget can be divided into operating and financial budgets.

Clauses 1)-5)are possessive relational process clauses which operate on attributive mode. The relational processes are realized by nominal groups include, consist of, can be broken down, and can be divided into. The verbal groups manifest possession in terms of classification owned by Carrier as classified. Whereas Attribute represents the classification. The Carrier is realized by nominal group The main types, These techniques, Product costs, The conversion costs category, A master budget. The analysis of the clauses above is illustrated in the table of analysis below.

\begin{tabular}{|c|c|c|}
\hline The main types & include & $\begin{array}{l}\text { variable air, mica, paper, ceramic, plastic, } \\
\text { titanium oxide and electrolytic }\end{array}$ \\
\hline These techniques & include & $\begin{array}{l}\text { combining resistors in series or parallel, } \\
\text { voltage division, and delta-to-wye and } \\
\text { wye-to-delta transformations }\end{array}$ \\
\hline Product costs & consist of & $\begin{array}{l}\text { direct materials, direct labor, and } \\
\text { overhead }\end{array}$ \\
\hline $\begin{array}{l}\text { The conversion } \\
\text { costs category }\end{array}$ & $\begin{array}{l}\text { can be broken } \\
\text { down into }\end{array}$ & direct labor and overhead \\
\hline $\begin{array}{l}\text { The conversion } \\
\text { costs category }\end{array}$ & can be divided into & operating and financial budgets \\
\hline Carrier & $\begin{array}{l}\text { Process: } \\
\text { attributive }\end{array}$ & Attribute \\
\hline Nominal group & Verbal group & Nominal group \\
\hline
\end{tabular}

Operating on attributive relational process, the clauses are not reversible as a characteristic of a clause which possesses an attributive process. This can be probed by 
using question “What types/kinds do Carrier possess?”. The answer is found in Attribute.

\section{Composition}

Composition according to https://dictionary.cambridge.org/dictionary/english/composition is defined as the parts, substances, etc. that something is made of. This is called meronymyin semantics which is a term used to describe a part-whole relationship between lexical items (Sayeed, 2016: 66). For example, wheel, engine, window, door, etc. are parts of a car. In other words, a car has wheel, engine, window, door, etc as its parts which compose it. This part-whole relation may be manifested in possessive clause as shown by Khorina et al (2017). Some possessive clauses taken from Electronics and Energy engineering texts express the role of Composition.

6) A simple electric circuitconsists of three basic elements: a battery, a lamp, and a connecting wire.

7) The current icomprises three components.

8) Passive filters are constructed with resistors, capacitors, and inductors.

9) A.C. bridges contain four impedance arms, an a.c. power supply and a balance detector

10) Each type of BJT has three terminals, designated as emitter (E), base (B), and collector $(C)$.

11) Attenuation sections are made up of resistances.

The clauses 6) - 11) belong to possessive relational process clauses operating on attributive relational process. The attributive relational processes are realized by verbal groupconsists of, comprises, are constructed with, contain,has, are made up of. These verbal groups manifest possession which construes the entity of composition realized by nominal groups of Attribute. The nominal groups represent meronyms or parts of Carrier to show parts-whole relationship. 


\begin{tabular}{|c|c|c|}
\hline $\begin{array}{l}\text { A simple electric } \\
\text { circuit }\end{array}$ & consists of & $\begin{array}{l}\text { three basic elements: a battery, a } \\
\text { lamp, and connecting wires. }\end{array}$ \\
\hline The current $i$ & comprises & three components. \\
\hline Passive filters & $\begin{array}{l}\text { are constructed } \\
\text { with }\end{array}$ & resistors, capacitors, and inductors. \\
\hline A.C. bridges & contain & $\begin{array}{l}\text { four impedance arms, an a.c. power } \\
\text { supply and a balance detector }\end{array}$ \\
\hline Each type of BJT & has & $\begin{array}{l}\text { three terminals, designated as emitter } \\
(E), \text { base }(B), \text { and collector }(C)\end{array}$ \\
\hline A capacitor & consists of & $\begin{array}{l}\text { two conducting plates separated by an } \\
\text { insulator (or dielectric). }\end{array}$ \\
\hline Attenuation & are made up of & Resistances. \\
\hline Carrier & $\begin{array}{l}\text { Process: } \\
\text { attributive }\end{array}$ & Attribute \\
\hline Nominal group & Verbal group & Nominal group \\
\hline
\end{tabular}

Based on the table analysis above, all clauses are classified as having attributive relational process. Consequently, the clauses are cannot be revised. Thus, for example, three basic elements: a battery, a lamp, and connecting wires consist of it (a simple electric circuit is not acceptable.

\section{Properties}

The third role played by possessive relational process clauses idientified by Khorina et al (2017) is Properties. In scientific term, aproperty is defined by Callister Jr. and Rethwisch $(2015,3)$ as a material trait in terms of the kind and magnitude of response to a specificimposed stimulus. This is like personalities owned by a person. This role is realized in scientific texts by possessive relational process clauses as exemplified below.

12) A first-order circuit is characterized by a first-order differential equation

13) A rectifier has a low impedance 
14) Dielectric materials have very high resistivities

15) Magnetite possesses magnetic properties

16) Every system of electrical conductors possesses capacitance

The five clauses are possessive relational process clauses working on attributive relational process. Again, this process expresses the entity of possession in terms of parts-whole relationship. The whole is represented by Carrier realized by nominal groups while the parts are manifested by Attribute realized by nominal groups as seen in the following table of analysis.

\begin{tabular}{|l|l|l|}
\hline A first-order circuit & is characterized by & $\begin{array}{l}\text { a first-order differential } \\
\text { equation }\end{array}$ \\
\hline A rectifier & has & a low impedance \\
\hline Dielectric materials & have & very high resistivities \\
\hline Magnetite & possesses & magnetic properties \\
\hline $\begin{array}{l}\text { Every system of electrical } \\
\text { conductors }\end{array}$ & possesses & capacitance \\
\hline Carrier & $\begin{array}{l}\text { Process: } \\
\text { possession }\end{array}$ & Attribute \\
\hline Nominal group & Verbal group & Nominal group \\
\hline
\end{tabular}

It can be seen clearly in the table analysis above that attributive relational processes are realized by various lexical verbs: characterize, have, and possess. These processes link the participants involved in the clauses which are called Carrier and Attribute. The Carrier and Attribute are realized by nominal groups.

\section{METHODOLOGY}

This study used qualitative method with data source from four English textbooks about Electronics and Energy engineering. The four textbooks are Electrical Circuit Theory and Technology (sixth edition), Fundamentals of Electronics Circuits (fifth edition), Electronics Fundamentals Circuits, Devices, and Applications(eighth edition), 
and A Textbook of Electrical Technology(23rd Edition) which are used by Electronics and Energy Engineering students of Politeknik Negeri Bandung as references.

The stages of this study can be seen in Figure 2. First, all possessive clauses were collected. Then, the selected clauses were classified according to the relational process they belong to. After that, they are divided based on the roles they play. Finally, they are analyzed before conclusion was drawn.

\section{Step 1}

All possessive clauses were collected.

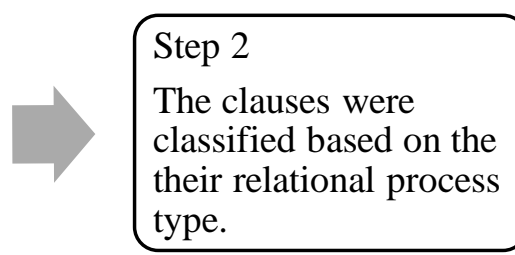

$$
\begin{aligned}
& \text { Step } 5 \\
& \text { The conclusion was } \\
& \text { drawn. }
\end{aligned}
$$

\section{Step 3}

They are divided based on the roles they play.

Figure 2. Steps in analyzing data

Step 4

They were analyzed to answer the research questions

\section{RESULTS AND DISCUSSION}

The data show all possessive relational process clauses tend to operate solely on attributive relational process. Theattributive relational process is realized by various lexical verbs: characterize, compose, comprise, consist, contain, construct, have, include, make, and possess. The most frequent lexical verbs which occur are haveand include. Besides, there are three roles played by the clauses which are known as Classification, Composition, and Properties (Figure 2.). Each of these roles are discussed below. 
The distribution of lexical verbs based on the roles of possessive relational process clauses

Classification $\square$ Composition $\square$ Properties

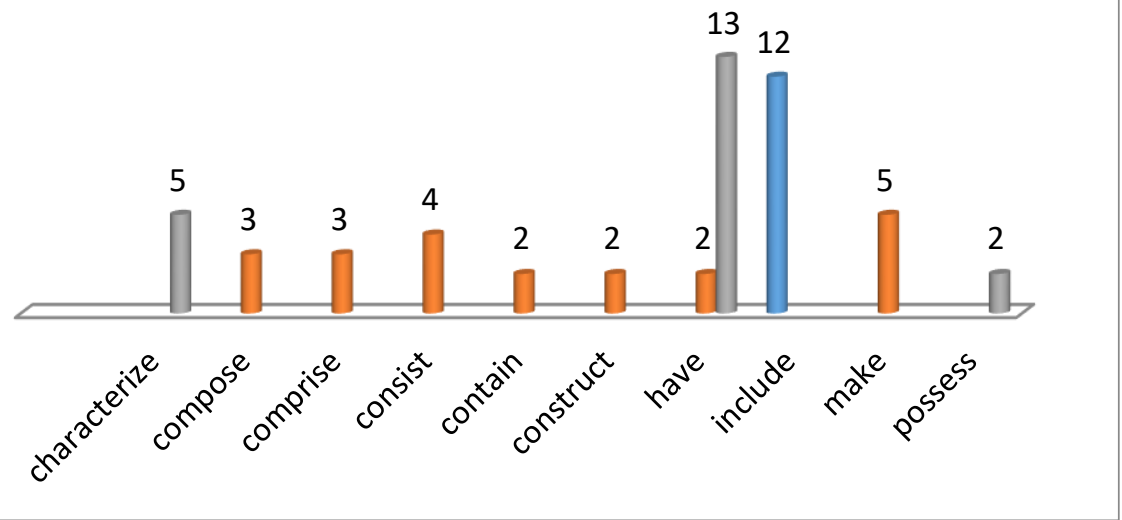

Figure 2. The distribution of lexical verbs based on the roles of possessive relational process clauses

\section{(Bird, 2017)Possessive relational process clauses as Classification}

Classification is a nature of scientific thinking. It is represented in scientific language and may be realized by possessive relational process clauses with attributive relational process as seen the clauses $(1)-(5)$.

(1) Practical applications of electrolysis include the electro plating of metals, the refining of copper and the extraction of aluminium from it sore.

(2) The effects of corrosion include the weakening of structures, the reduction of the life of components and materials, the wastage of materials and the expense of replacement.

(3) The main types include variable air, mica, paper, ceramic, plastic, titanium oxide and electrolytic, together with supercapacitors.

(4) These techniques include combining resistors in series or parallel, voltage division, and delta-to-wye and wye-to-delta transformations.

(5) Such devices include conducting wire, light bulbs, electric heaters, stoves, ovens, and loudspeakers.

The process is realized solely by one type of lexical verb - include indicating that Carrier realized by nominal groups possess some typesor homonyms. The types are represented by Attribute realized by nominal groups. These nominal groups contain 
coordinate conjunction that show paralalelism. It could be seen in the table of analysis below.

\begin{tabular}{|l|l|l|}
\hline $\begin{array}{l}\text { Practical } \\
\text { applications of } \\
\text { electrolysis }\end{array}$ & include & $\begin{array}{l}\text { the electro plating of metals, the refining } \\
\text { of copper and the extraction of aluminium } \\
\text { from it sore. }\end{array}$ \\
\hline $\begin{array}{l}\text { corrosion } \\
\text { The main types }\end{array}$ & include & $\begin{array}{l}\text { the weakening of structures, the reduction } \\
\text { of the life of components and materials, } \\
\text { the wastage of materials and the expense } \\
\text { of replacement. }\end{array}$ \\
\hline These techniques & include & $\begin{array}{l}\text { variable air, mica, paper, ceramic, } \\
\text { plastic, titanium oxide and electrolytic, } \\
\text { together with supercapacitors. }\end{array}$ \\
\hline Such devices & include & $\begin{array}{l}\text { combining resistors in series or parallel, } \\
\text { voltage division, and delta-to-wye and } \\
\text { wye-to-delta transformations. }\end{array}$ \\
\hline Carrier & include & $\begin{array}{l}\text { conducting wire, light bulbs, electric } \\
\text { heaters, stoves, ovens, and loudspeakers. }\end{array}$ \\
\hline Nominal group & Verbal group & Nominal group \\
\hline
\end{tabular}

To probe that the clauses play the role of Classification, the question "How many kinds do the practical applications of electrolysis have?" for example. The answer is "the electro plating of metals, the refining of copper and the extraction of aluminium from it sore"found in Attribute.

\section{Possessive relational process clauses as Composition}

The next role of possessive relational process clauses is Composition. The five clauses below belong to possessive relational process clauses working on attributive mode.

(6) A capacitor consists of two conducting plates separated by an insulator.

(7) Asecond-order circuit may contain several resistors and dependent and independent sources.

(8) Passive filters are constructed with resistors, capacitors, and inductors.

(9) An ideal op amp has an infinite input resistance, a zero output resistance, 
and an infinite gain.

(10) A complete circular lamination is made up of four or six or even eight segmentallaminations.

The attributive relational process is realized by several verbal groups. They are consists of, contain, are constructed with, has, and is made up of. As seen here, two of the verbal groups are structured in passive form: are constructed with are is made up of while the others are in active forms. These verbal groups link one participant in the clauses which possess the parts or composition with other participants which realize the parts or composition.

Semantically, the parts are meronyms of the entity. The parts are represented by Attribute while the entity which possesses the parts is represented by Carrier. Attribute is realized by nominal groups in plural formstwo conducting plates, four or six or even eight segmental laminations or containing coordinate conjunction or/and, several resistors and dependent and independent sources, resistors, capacitors, and an infinite input resistance, a zero output resistance, and an infinite gainas seen in the table of analysis below.

\begin{tabular}{|l|l|l|}
\hline A capacitor & consists of & $\begin{array}{l}\text { two conducting plates separated by an } \\
\text { insulator. }\end{array}$ \\
\hline $\begin{array}{l}\text { Asecond-order } \\
\text { circuit }\end{array}$ & may contain & $\begin{array}{l}\text { several resistors and dependent and } \\
\text { independent sources. }\end{array}$ \\
\hline Passive filters & $\begin{array}{l}\text { are constructed } \\
\text { with }\end{array}$ & $\begin{array}{l}\text { resistors, capacitors, and inductors. } \\
\text { An ideal op amp }\end{array}$ \\
has & $\begin{array}{l}\text { an infinite input resistance, a zero } \\
\text { output resistance, and an infinite gain. }\end{array}$ \\
\hline Aamination & is made up of & $\begin{array}{l}\text { four or six or even eight segmental } \\
\text { laminations. }\end{array}$ \\
\hline Carrier & $\begin{array}{l}\text { Process: } \\
\text { possession }\end{array}$ & Attribute \\
\hline Nominal group & Verbal group & Nominal group \\
\hline
\end{tabular}


Based on the table of analysis above, it can be inferred that Composition is realized by possessive clauses operating on single relational process type - attributive. However, the attributive relational process may be realized by several lexical verbs either in active or in passive forms as discussed above. To probe that the clauses play the role of Properties, the question "What parts does a capacitor have?". The answer istwo conducting plates separated by an insulator which is represented by Attribute.

\section{Possessive relational process clauses: as Properties}

The last role played by possessive relational process clauses is Properties. There are 20 clauses play the role of Properties. The four clauses below were taken from the data to be discussed.

(11) The single-element semiconductors are characterized by atoms with four valence electrons.

(12) Intrinsic semiconductors have resistive properties.

(13) Coils have very large reactances.

(14) Every system of electrical conductors possesses capacitance.

The possessive relational process clauses above work on attributive mode realized by verbal groups are characterized by, have, and possess. The verbal groups may be in the form of active or passive. But, they indicate that one participant owns properties which is realized by another participant in the clause. Properties are realized by nominal groups which represent Attribute while the entity having the properties is represented by Carrier. The nominal groups, unlike nominal groups which appear in Classification and Composition, do not contain coordinate conjunctions. However, they tend to have modifier or qualifier. To probe that the clauses have the role of Properties, the question "What properties does coils have?". The answer is very large reactances which is found in Attribute. This can be seen in table analysis below. 


\begin{tabular}{|l|l|l|}
\hline $\begin{array}{l}\text { The single-element } \\
\text { semiconductors }\end{array}$ & $\begin{array}{l}\text { are characterized } \\
\text { by }\end{array}$ & $\begin{array}{l}\text { atoms with four valence } \\
\text { electrons. }\end{array}$ \\
\hline Intrinsic semiconductors & have & high resistivities \\
\hline Coils & have & very large reactances. \\
\hline $\begin{array}{l}\text { Every system of electrical } \\
\text { conductors }\end{array}$ & possesses & capacitance. \\
\hline Carrier & $\begin{array}{l}\text { Process: } \\
\text { possession }\end{array}$ & Attribute \\
\hline Nominal group & Verbal group & Nominal group \\
\hline
\end{tabular}

\section{Possessive relational process clauses: implication on teaching ESP}

The possessive relational process clauses found in scientific texts play three roles: Classification, Composition, and Properties. Being familiar with these roles may help learners of ESP understand scientific texts easily since each role possesses specific features. Referring to the analysis previously presented, the learners with grammatical weaknesses could focus on certain number of lexical verbs which are used in specific roles instead of learning all aspects of grammar. In addition, those learners who have difficulties in working with passive voices, they can concern with the verbal groups.

\section{CONCLUSION}

Having presented the discussion of the role of possessive clauses in scientific texts above, it can be drawn some conclusions. Possessiverelational process clauses have certain specific roles in scientific texts. They are Classification which informs about taxonomy. The clauses operate solely on attributive mode realized only by a lexical verb include. Then, the possessive relational process clauses also play the role of Composition. Like previous role, this role is realized by possessive relational process clauses working on attributive mode. The attributive relational process is realized by various lexical verbs: consist, contain, construct, have, and make. The last role played by possessive relational process clauses is Properties. The clauses which realize this role possess attributive relational processes realized by lexical verbs characterize, have, and 
possess.

Being familiar with the roles played by the possessive relational process clauses in scientific texts will help ESP learners understand scientific texts easily. Each role possesses specific structure using limited lexical verbs. This prevents the learners from memorizing complex and complicated structures. As a result, they will not be alienated with the texts.

\section{REFERENCES}

Alexander, K. C., \& Sadiku, M. N. (2016). Fundamental of Electric Circuits, 6th Edition. United States: McGraw-Hill Education.

Barthes, R. (1977). Element of Semilology. New York: Hill and Wang.

Basturkmen, H. (2010). Developing Courses in English for Specific Purposes. London: Palgrave Macmillan.

Bird, J. (2017). Electrical and Electronic Principles and Technology, 6th Edition. Oxon: Routledge.

Chandler, D. (2002). Semiotics: The Basics. London: Routledge.

Darian, S. (2003). Understanding the Language of Science. Austin: Texas Publishing Press.

Fairclough, N. (2003). Analyzing Discourse: textual Analysis for Social Research. London: Longman.

Floyd, T. L., \& Buchla, D. L. (2014). Electronics Fundamentals Circuits, Devices and Applications, 8th Edition. Essex: Pearson Education Limited.

Gandasudirdja, R. M. (1977). 700 Paribasa Sunda. Bandung: Firma Ekonomi.

Graham, A. (2000). Intertextuality (The New Critical Idiom). London: Routlege.

Halliday, M. (1994). An Introduction to Functional Grammar, 2nd Edition. London: Hodder Education.

Halliday, M., \& Hasan, R. (t.thn.).

Halliday, M., \& Martin, J. R. (1993). Some Grammatical Problems in Scientific Texts. Dalam M. Halliday, Writing Science: Literacy and Discursive Power (hal. 6885). London: The Falmer Press. 
Halliday, M., \& Matthiessen, C. M. (2004). An Introduction to Functional Grammar, 3rd Edition. London: Hodder Education.

Halliday, M., \& Matthiessen, C. M. (2014). An Introduction to Functional Grammar, 4th Edition. London: Routledge.

Khorina, M., Suyatna, E., \& Indira, D. (2017). Relational Process in Scientific Texts: Afunctional Grammar Approach. Bandung: Faculty of Cultural Science, Universitas Padjadjaran.

Marcel Danesi, Paul Perron. (1999). Analyzing Cultures: An Introduction and Handbook. Indiana: Indiana University Press.

Martin, J. R. (1992). English Texts: System and Structure. Amsterdam: John Benjamins Publishing Company.

Moleong, L. J. (2007). Metodologi Penelitian Kualitatif. Bandung: PT Remaja Rosada Karya.

Nasrudin. (2010). Kearifan Lokal dalam Pappaseng Bugis. Jurnal Sawerigading, Vol 16 No. 2. org, d. c. (2018, September 19). https://dictionary.cambridge.org/dictionary/english/composition. Diambil kembali dari https://dictionary.cambridge.org/dictionary/english/composition

Paltridge, B., \& Starfield, S. (2013). Introduction. Dalam B. Paltridge, \& S. Starfield, The Handbook of English for Specific Purposes (hal. 1-4). West Sussex: John Wiley \& Sons, Inc.

Prawirasumantri, A. e. (1973). Idiomatik Sunda. Bandung: FKKS.

Rahyono, F. (2011). Kearifan Budaya dalam Kata. Bandung: Kiblat Utama.

Rohaedi, A. (1986). Kepribadian Budaya Bangsa (Local Genius). Jakarta: Pustaka Pelajar.

Rosidi, A. (2011). Babasan \& Paribasa. Bandung: Kiblat Utama.

Sayeed, J. I. (2003). Semantics. Oxford: Blackwell Publishing.

Schleppegrell , M. J. (2004). the Language of Schooling: A Functional Linguistics Perspective. New Jersey: Lawrence Erlbaum Associates, Inc., Publishers .

Sembiring, B. (2018). The Language of Classification in Accounting Texts in the Framework of SFL. Jurnal Bahasa Inggris Terapan, Volume 4 No 1, 34-47.

Siti Kodariah, Gugun Gunardi. (2015). Nilai Kearifan Lokal dalam Peribahasa Sunda, Kajian Semiotika. Patanjala, Vol . 7 No. 1.

Sudrajat. (2003). Elmuning Basa. Bandung: Wahana Luang. 
Sugara, H. (2016). Values of Local Wisdom of Sundanese Proverb. Journal of Indonesia Language Education and Literary, Vol 1, No. 2.

Tamsyah, B. R. (1994). 1000 Babasan jeung Paribasa. Bandung: Pustaka Setia.

Theraja, B., \& Theraja, A. (1999). A Textbook of Electrical Technology, AC and DC Machines. New Delhi: S. Chand \& Company Ltd.

Theraja, B., \& Theraja, A. (1999). A Textbook of Electrical Technology, AC and DC Machines. New Delhi: S. Chand \& Company Ltd.

Wagiati, Sugeng Riyanto. (2015). Peribahasa Sunda sebagai Sumber Kearifal Lokal. International Conference on Language, Culture, and Society. Jakarta: Lembaga Ilmu Pengetahuan Indonesia.

Wellington, J., \& Osborne, J. (2001). Language and Literacy in Science Education. Buckingham: Open University Press.

Wignell, P., Martin, J., \& Eggins, S. (1993). The Discourse of Geography: Ordering and Explaining the Experiential World. Dalam M. Halliday, \& J. Martin, Writing Science: Literacy and Discursive Power (hal. 136-165). London: The Falmer Press.

Yuliawati, S. (2018). Nilai-Nilai Kerukunan Dalam Pepatah Sunda: Kajian Semiotik Tentang Kearifan Lokal. Dalam D. Reiza Diena Putra, Menjejaki Integritas Social Budaya (hal. 43 - 62). Bandung: Balatin Pratama. 